\title{
Changing decisions in a changing landscape: How might forest owners in an urbanizing region respond to emerging bioenergy markets?
}

\author{
Monica A. Dorning*, Jordan W. Smith, Douglas A. Shoemaker, Ross K. Meentemeyer \\ North Carolina State University, Center for Geospatial Analytics, Raleigh, NC 27695, USA
}

\section{A R T I C L E I N F O}

\section{Article history:}

Received 24 November 2014

Received in revised form 5 May 2015

Accepted 23 June 2015

\section{Keywords:}

Contingent behavior

Stated preference

Woody biomass

Bioenergy market

Forest owners

\begin{abstract}
A B S T R A C T
The global bioenergy market has considerable impacts on local land use patterns, including landscapes in the Southeastern United States where increased demand for bioenergy feedstocks in the form of woody biomass is likely to affect the management and availability of forest resources. Despite extensive research investigating the productivity and impacts of different bioenergy feedstocks, relatively few studies have assessed the preferences of private landowners, who control the majority of forests in the eastern U.S., to harvest biomass for the bioenergy market. To better understand contingent behaviors given emerging biomass markets, we administered a stated preference experiment to private forest owners in the rapidly urbanizing Charlotte Metropolitan region. Respondents indicated their preferences for harvesting woody biomass under a set of hypothetical market-based scenarios with varying forest management plans and levels of economic return. Our analytical framework also incorporated data from a previously-administered revealed preference survey and spatially-explicit remote sensing data, enabling us to analyze how individuals' ownership characteristics, their emotional connection the forests they manage, and the spatial patterns of nearby land uses, influence willingness to grow bioenergy feedstocks. We found conditional support for feedstock production, even among woodland owners with no history of active management. Landowners preferred higher economic returns for each management plan. However low-intensity harvest options were always preferred to more intensive management alternatives regardless of economic return, suggesting that these landowners may be more strongly motivated by aesthetic or quality-of-life concerns than feedstock revenues. Our analysis indicated preferences were dependent upon individual and environmental characteristics, with younger, more rural landowners significantly more interested in growing feedstocks relative to their older and more urban counterparts. While this study focuses on one small sample of urban forest owners, our results do suggest that policy makers and resource managers can better inform stand-level decision-making by understanding how feedstock production preferences vary across populations.
\end{abstract}

Published by Elsevier Ltd.

\section{Introduction}

The emerging global bioenergy market is expected to have major impacts on land management decisions (Dale et al., 2011) with land dedicated to bioenergy production displacing other land use types such as timberland and farmland (White et al., 2014). In the United States, bioenergy has emerged as a key component of the nation's energy independence strategy with government targets for 137 billion liters of fuel from plant materials by 2022 (Energy

\footnotetext{
* Corresponding author. Present address: Geosciences and Environmental Change Science Center, U.S. Geological Survey, Lakewood, CO 80225 USA.

E-mail addresses: mdorning@usgs.gov (M.A. Dorning),jwsmit12@ncsu.edu (J.W.Smith), dashoema@ncsu.edu (D.A.Shoemaker),rkmeente@ncsu.edu (R.K. Meentemeyer).
}

Independence and Security Act of 2007, 2007). This demand is expected to result in large-scale supply-side responses from both the forest and agricultural sectors (White et al., 2014); in the Southeast the amount of harvested woody biomass used for bioenergy is projected to grow from 170 to 336 million green tons by 2050 (Alavalapati et al., 2011) and ethanol production is already on the rise in the Midwest (Fletcher et al., 2011). While bioenergy production systems could reduce dependence on foreign oil and the emission of greenhouse gases into the atmosphere (Fletcher et al., 2011), the true environmental and ecological benefits are controversial. The full-scale development of bioenergy feedstock production systems is expected to trigger regional land cover and land use change, affecting current hydrological and biogeochemical balances and perhaps competing with food crops and urbanization for suitable land (Alavalapati et al., 2011). Whether or not bioenergy can 
become a sustainable alternative will depend on which feedstocks are used, how they are produced, and the changes in land use and management practices that result (Fargione et al., 2008; Field et al., 2008; Robertson et al., 2008; Dale et al., 2011; Fletcher et al., 2011).

\subsection{Bioenergy in the Southeastern United Statues}

Many of the existing studies regarding bioenergy feedstock production in the United States focus predominantly on Midwestern farmers (e.g., Jensen et al., 2007; Cope et al., 2011), however the management options in the Southeastern United States are very different given dissimilarities between the two regions' socioeconomic and ecological systems. In addition to the energy grasses and crops common in the Midwest, southeastern landscapes are also suitable for growing woody biomass harvested from forested land (Dale et al., 2011). Woody biomass is a highly viable bioenergy source in the region given production to consumption supplychains are already established via existing timber markets (Scott and Tiarks, 2008; Abt et al., 2010). Changes in biomass use are already occurring in this region as a result of increased demand for wood pellets to supply European energy markets (Sikkema et al., 2011).

Management options for producing woody biomass for bioenergy production typically involve short-rotation harvesting schedules or a combination of conventional harvest (for timber or pulp markets) with the sale of harvest residues for bioenergy feedstocks. Short-rotation management resembles typical monoculture plantations, with densely planted woodlots harvested on a regular basis (typically 3-12 years; White, 2010). Yields from these plantations vary with species, growing time, and stem density (Adegbidi et al., 2001; Stanton et al., 2002; Volk et al., 2006). Alternatively, conventional harvests for saw timber or pulpwood conducted at 25-50 year cycles could be supplemented with extraction of timber residues (e.g., non-marketable branches and tops of stems) for woody biomass; however the total removal of all residues post-harvest could have impacts on soil nutrient cycling and reforestation rates (Johnson and Curtis, 2001; Johnson et al., 2002). Uneven-aged stand thinning could emerge as a third alternative to produce woody biomass for bioenergy production with potential economic and ecological benefits, such as improving understory plant diversity (Thomas et al., 1999). This option is expected to be profitable only if some trees are harvested at higher prices for saw timber or pulpwood (U.S. Department of Energy, 2011) and can be conducted on a 5-15 year cycle (Skog et al., 2006). The adoption of any of these options on private forestlands within the Southeast would likely involve changes from current forest management strategies, however little is known about where and when these changes might occur and what the subsequent impacts to forest resources will be.

\subsection{Landowner preferences}

Research on the productivity and environmental impacts of various bioenergy feedstocks is commonplace relative to investigations into the opinions, values, and contingent behaviors of private landowners who are key players in the sustainable production of bioenergy feedstocks (Perez-Verdin et al., 2009; Silver et al., 2015). The emerging demand for bioenergy presents woodland owners with new management possibilities, giving them the opportunity to alter their current management practices in order to grow and sell feedstocks for bioenergy production. Motivation to change existing management practices may stem from the promise of economic gain or from government tax incentives or subsidies (Jensen et al., 2007; Shivan and Mehmood, 2010). However landowners are often hesitant to change their land use practices, especially when their current system is economically profitable (Jensen et al., 2007), and are thus likely to view feedstocks as an interstitial crop rather than a primary source of income (Cope et al., 2011). Economic concerns are frequently the major reason for reluctance; fears about the market, uncertainty over immediate monetary returns and long-term profitability, and the high cost of change, have all been documented as major barriers to landowners' willingness to engage in emerging bioenergy markets (Jensen et al., 2007; Cope et al., 2011). Additionally, many potential bioenergy feedstock suppliers are relatively uninformed regarding bioenergy production and may not fully understand the range of options available for supplementing (or replacing) their existing land use practices with biomass harvesting (Grebner et al., 2009; Nassauer et al., 2011; Joshi et al., 2013a).

Abundant research has related forest management choices to landowners' socio-demographic characteristics (Amacher, 2003; Beach et al., 2005) and recent studies focusing specifically on forest owner preferences for growing bioenergy feedstocks found similar results. For example, landowner age and education level, the size of the forest holding, and a history of timber harvest have been associated with interest in producing feedstocks (Joshi and Mehmood, 2011; Gruchy et al., 2012; Shivan and Mehmood, 2012; Joshi et al., 2013b). In addition to socio-demographic characteristics, Cope et al. (2011) found farmers in Illinois who expressed strong personal attachments to their current farming practices were less willing to change their management strategies to grow energy crops. Environmental impacts may also be of concern; Jensen et al. (2007) found farmers were less willing to produce switchgrass for bioenergy if they also had an interest in providing wildlife habitat on their land, while Gruchy et al. (2012) and Joshi and Mehmood (2011) found forest owners had greater interest in harvesting timber for bioenergy markets if they also included provision of wildlife habitat as a management objective. Similarly, Joshi et al. (2013b) found landowners were more willing to allow woody biomass harvesting from their forests if the harvesting method minimized damage to the surrounding environment and involved limited site preparation.

Along with the individual-level characteristics noted above, local land use patterns might influence landowners' willingness to manage their landscape for bioenergy production. Previous research has shown that forest management and harvesting activities decline with urbanization (Barlow et al., 1998; Kline et al., 2004). For example, forest owners in rapidly urbanizing areas might be less willing to allow woody biomass to be harvested from their property if adjacent and nearby lands are being developed. The likely rise in property values associated with urban expansion (Plantinga et al., 2002) will make it increasingly difficult for urban-proximate forest owners to commit to long-term forest management plans. If this is true, it is unfortunate given that woody-biomass harvested from urban and peri-urban areas represent a large and underutilized feedstock source (MacFarlane, 2009; McKeever and Skog, 2003). Our investigation explores this relationship by uniquely combining revealed preference data collected via surveys with metrics derived from remotely sensed imagery.

\subsection{Research approach}

In this study we examined the willingness of a group of nonindustrial private forest owners in an urbanizing region to produce woody biomass for the production of bioenergy. Specifically, we asked:

a Are private forest owners interested in growing woody biomass for bioenergy;

b What types of forest management would they choose;

c What rates of economic return would they prefer under each management option; and 
d How do socio-demographic characteristics, personal values, and landscape context influence their decisions?

Analysis of the actual behaviors of woodland owners for growing feedstocks in the Southeast is nearly impossible due to the limited existence of a current market for woody biomass (Alavalapati et al., 2011). Therefore, we developed a stated preference experiment to estimate the probability that private forest owners would be willing to grow woody biomass for bioenergy under a set of hypothetical market-based scenarios.

Collectively, past research, theory and logic suggest land use decisions related to bioenergy production are influenced by landowners' socio-demographic characteristics, their personal values, and local land use patterns. To identify potential decision drivers, stated preference survey responses were combined with: (1) Data for the same woodland owners from previouslyadministered revealed preference survey; (2) Remote sensing analysis to contextualize woodland size and location within the surrounding urbanizing landscape mosaic; and (3) Appraised real estate value from concurrent parcel data. The resultant stack of spatially-explicit social, economic, and biophysical data revealed how the attributes of different feedstock production scenarios and individuals' ownership characteristics influenced preferences for growing woody biomass for bioenergy and how those potential decisions might influence landscape composition.

\section{Methods}

This study is one of a suite of studies conducted as part of the Charlotte Urban Long Term Research Area (ULTRA-Ex) program (e.g., Meentemeyer et al., 2013; BenDor et al., 2014). This program was designed to examine responses of private forest owners to landscape change in the Charlotte, North Carolina metropolitan region. Rapid urban growth is transforming this landscape from predominantly rural and agricultural to one of intense urban and suburban development. Despite these pressures, Charlotte is notable for its substantial urban and periurban tree canopy, estimated at $46 \%$ by American Forests (2010), and one of the highest in the nation for medium to large cities. The majority of forested land in this region is made up of small holdings owned by non-industrial private forest owners, but increasing property taxes and lack of economic incentives may leave these individuals with limited options for maintaining their properties in this rapidly changing environment (BenDor et al., 2014). Given the expected rise in global demand for bioenergy feedstocks from the Southeast, it is possible the emergence of regional markets for woody biomass might provide forest owners with a new option for generating income from their land, providing some relief from increasing tax costs (Alavalapati et al., 2011).

\subsection{Study population}

We surveyed participants from a network of forest owners established by the Charlotte ULTRA-Ex program in 2011 (BenDor et al., 2014). For that program, individuals were targeted who owned forested properties within six counties on the eastern side of the Charlotte Metropolitan region, an extent representative of the gradient of urban and rural landscape characteristics in this rapidly growing area (Fig. 1). At the time of selection, privately owned forests comprised $39 \%$ of remaining forest land across nearly 8000 holdings, with many individuals owning multiple properties (BenDor et al., 2014). Nearly 78\% of those privately owned forests were under 8.3 ha (mean $=6.7 \mathrm{ha}$ ). The forests covered a broad spectrum of characteristics, from small hardwood remnants near the center city to relatively larger pine plantations on its outskirts.
Participants in the study were required to have sole or family ownership of a minimum forested stand of 2.5 ha, complete a series of confidential surveys, and grant access for field crews to conduct an ecological assessment and timber cruise of forested holdings. Due possibly to anti-government sentiment prevalent in the region and liability concerns arising from the requirement that researchers be permitted to access the property, the response rate to participate in the program was $5 \%$. Additional details regarding selection of participants and their typologies are described by BenDor et al. (2014).

\subsection{Stated preference survey design}

We developed a stated preference survey to explore contingent landowner behaviors given hypothetical market-based scenarios with two varying attributes: the type of forest management plan implemented and the amount of economic return expected. We mailed the stated preference survey to all 126 landowners that returned completed revealed preference surveys as part of the Charlotte ULTRA-Ex program. In the survey packet, we included a personalized map with an aerial photo of the forest stand of interest. We asked the landowner to respond to the questions in reference to this single forested parcel, excluding from consideration any other forested properties they happened to own. This allowed us to link individual survey data to a specific forest in the landscape and its location along an urban-to-rural gradient identified using remote sensing.

\subsubsection{Scenario attributes}

We implemented a full factorial experimental design with three types of management plans and three levels of economic return for a total of nine different combinations or scenarios. We designed the scenarios to encompass a range of conditions, some which may be economically feasible now or in the near future and others that could emerge depending on the trajectory of the bioenergy market. For each scenario, we asked the landowner what proportion of their forested property they would dedicate to feedstock production given the specified management plan and economic return. Following standard practice in the design of stated preference experiments (Bennett and Blamey, 2001; Ryan and Skåtun, 2004), we included an opt-out option in which landowners could indicate they would never harvest woody biomass for the bioenergy market and provide a short description of their reasons for this choice.

The three types ('levels' in the common vernacular of stated preference experiments; Louviere et al. 2000) of land management described in the scenarios included stand thinning, conventional harvest, and short-rotation plans. We described stand thinning as a management strategy where a selection of uneven-aged trees could be removed for sale as timber with smaller trees and branches sold to create woody biomass (Skog et al., 2006; U.S. Department of Energy, 2011). A full conventional harvest included removal of most or all trees and residues for sale as a combination of timber and biomass (White, 2010). A short-rotation plan involved high density planting of a single species for frequent harvest solely for the bioenergy market (Adegbidi et al. 2001; Volk et al., 2006; Hinchee et al., 2009).

We included three levels of return - $\$ 50, \$ 150$, and $\$ 250$ per acre per year - based on current and projected regional market demand for woody feedstocks (U.S. Department of Energy, 2011; Forest2Market, 2012) and estimates of per acre productivity (Skog et al., 2006; Hinchee et al., 2009; White, 2010). The harvest rotation intervals of the three management plans produce income at different time intervals. To make values comparable across scenarios we presented standardized projected revenue streams in terms of dollars per acre per year values and made them sum at 50 years, 


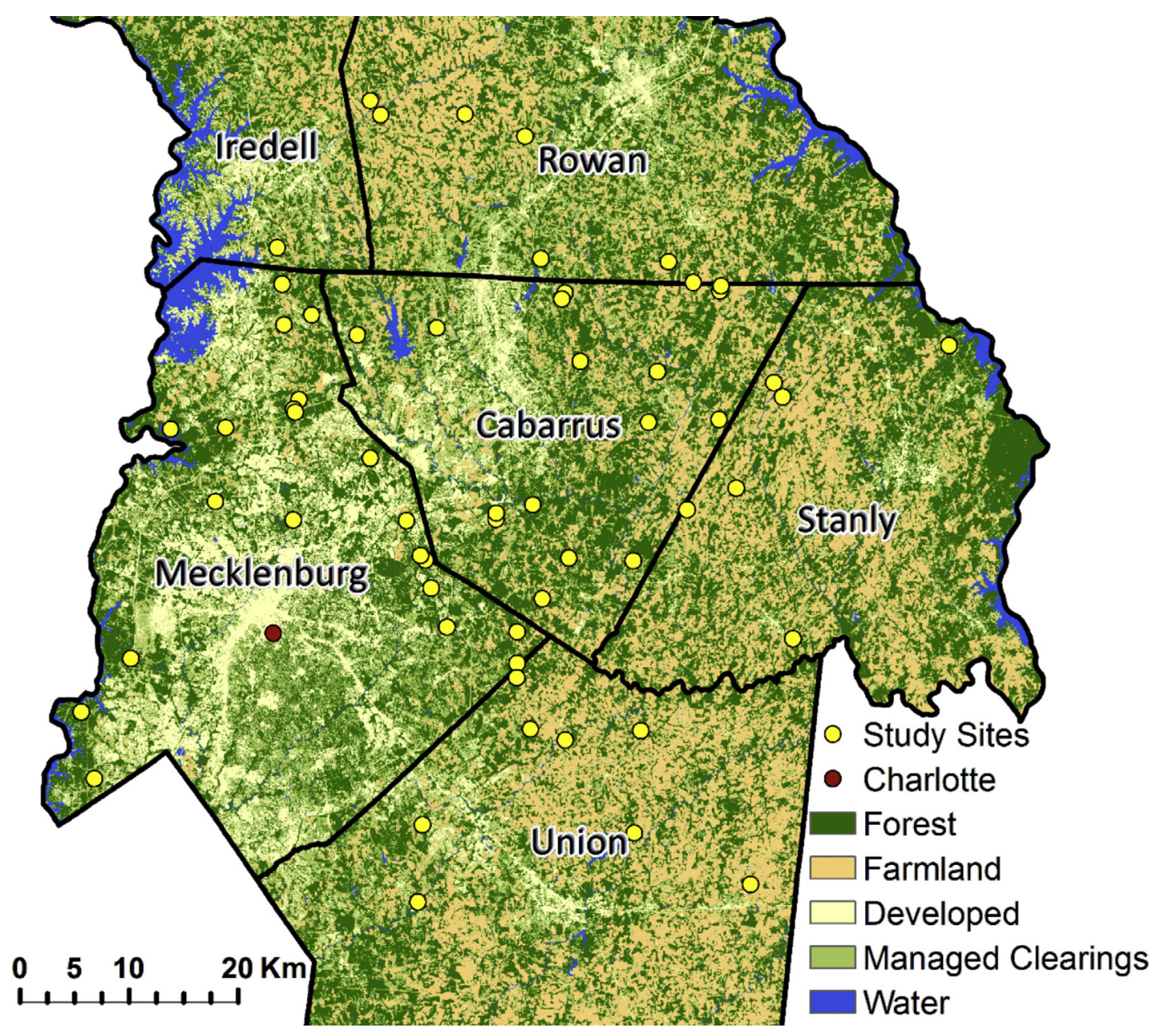

Fig. 1. Six-county study extent. Study sites include all landowners that participated in the stated preference survey $(n=60)$.

comparable to the rotation of a conventional harvest. The full set of questions asked of each landowner, including management plan descriptions, is included in Appendix A.

\subsubsection{Individual attributes}

In addition to testing the effects of the scenario attributes on landowners' willingness to grow bioenergy feedstocks, we were also interested in understanding how landowners' sociodemographic characteristics, their personal values, and local land use patterns influenced decision-making. Using data from remote sensing, county land records, and the previous study of landowners' revealed preferences, we derived a set of variables specific to each individual that we expected would influence their decisions (Table 1 ). The revealed preference survey included questions regarding forest management, personal values, and basic demographic information. From these data, we derived variables indicative of the landowner's age, presence on their property, and sense of place. The sense of place indicator variable was based on 9 statements from Jorgensen and Stedman's (2006) psychometric scale, modified to assess place values pertaining to wooded land (see Appendix B). Using responses from all 9 of these questions, we applied principal axis factoring in SPSS Version 21 (IBM Corp., 2012) to create a single unidimensional construct representing sense of place. The sense of place construct accounted for $63 \%$ of the variance across the 9 statement items and yielded a Cronbach's alpha of 0.925 ; we deemed the construct to be a highly reliable measure with more than adequate internal consistency among the individual statement items (Nunnally and Bernstein, 1994). We identified the total size of the landowner's forest using land cover data (forest, farmland, development, and water) that was classified by Singh et al. (2012) from a combination of 2011 Landsat and LiDAR data at a 30 meter spatial resolution. We also used this data to develop an indicator of the urban-to-rural gradient, represented here by the amount of farmland in the surrounding landscape. The property value of the forested parcel was represented by the appraised tax value extracted from county-level parcel data using a GIS.

\subsection{Model estimation}

For each of the nine scenarios, landowners had a choice: produce bioenergy feedstocks or do not produce bioenergy feedstocks. If we assume the landowners intend to maximize their own utility, we can estimate preferences for choosing to produce bioenergy feedstocks via a utility function following McFadden (1974): $\mathrm{U}_{\mathrm{njt}}=\mathrm{V}_{\mathrm{njt}}+\Sigma_{\mathrm{njt}}$, where $\mathrm{V}$ represents the systematic portion of individual n's utility for alternative $\mathrm{j}$ (the decision to produce feedstocks or not) in choice scenario $t$ and $\epsilon$ njt is the unobserved or random component of utility.

We used a mixed logit model to determine the probability that landowners would produce woody biomass in any portion of their forests depending on the scenario and individual level attributes. The mixed logit model explicitly accounts for variation in preferences across the population and for correlation in unobserved factors that arise over repeated observations from the same individual (Louviere et al. 2000; Gelman and Hill 2007; Train 2009). Here, the probability (Pr) of individual $\mathrm{n}$ choosing to produce feedstocks $(j)$ in choice scenario $t$ is determined by $\operatorname{Pr}\left(P_{\text {njt }}=1\right)=\left(E^{\text {Unjt }}\right)$. 
Table 1

Summary of scenario and individual attributes.

\begin{tabular}{|c|c|c|c|}
\hline Variable & Description & Mean & Std dev \\
\hline \multicolumn{4}{|l|}{ Scenario attributes } \\
\hline Management plan & Type of management required (three levels) & - & - \\
\hline Economic return & Amount of economic return expected (three levels) & - & - \\
\hline \multicolumn{4}{|l|}{ Individual attributes } \\
\hline Age & Age of landowner (years) & 64.2 & 11.2 \\
\hline Presence & Years of ownership* days on property per year (years) & 15.6 & 14.8 \\
\hline Sense of place & Factor score derived from 9 survey questions & 0 & 1 \\
\hline Forest size & Size of forested stand of interest (ha) & 6.9 & 8.4 \\
\hline Surrounding farmland & Farmland within a $2 \mathrm{~km}$ radius ( $1257 \mathrm{ha}$ ) of stand centroid (ha) & 298.9 & 222.9 \\
\hline Property value & Total appraised tax value of parcel $(\$ 1000)^{a}$ & 397.8 & 394.3 \\
\hline
\end{tabular}

a Tax value of parcel included forest stand of interest plus other land covers and improvements.

Table 2

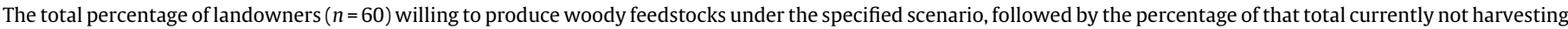

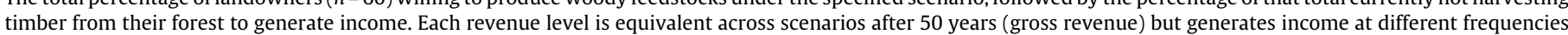
resulting in varying discounted values.

\begin{tabular}{|c|c|c|c|c|c|}
\hline \multicolumn{6}{|l|}{ Scenario } \\
\hline Management plan & Economic return ( $\$$-year-acre $)$ & $\begin{array}{l}\text { Willing to } \\
\text { produce (rank) }\end{array}$ & $\begin{array}{l}\text { Willing but not currently } \\
\text { harvesting (\%) }\end{array}$ & Gross revenue $(\$)^{\mathrm{a}}$ & $\begin{array}{l}\text { Discounted present } \\
\text { value }(\$)^{\mathrm{b}}\end{array}$ \\
\hline Stand thinning & 50 & $33 \%(3)$ & 80 & 38,750 & 13,867 \\
\hline Stand thinning & 150 & $48 \%(2)$ & 83 & 116,250 & 41,600 \\
\hline Stand thinning & 250 & $62 \%(1)$ & 84 & 193,750 & 69,334 \\
\hline Conventional harvest & 50 & $13 \%(7)$ & 62 & 38,750 & 5,452 \\
\hline Conventional harvest & 150 & $23 \%(5)$ & 64 & 116,250 & 16,357 \\
\hline Conventional harvest & 250 & $25 \%(4)$ & 67 & 193,750 & 27,263 \\
\hline Short-rotation & 50 & $13 \%(7)$ & 62 & 38,750 & 15,369 \\
\hline Short-rotation & 150 & $17 \%(6)$ & 70 & 116,250 & 46,107 \\
\hline Short-rotation & 250 & $23 \%(5)$ & 64 & 193,750 & 76,845 \\
\hline
\end{tabular}

a After 50 years in 2011 dollars.

b Discounted cash flow at a $4 \%$ annual discount rate.

In this equation, utility is a function of scenario and individual specific attributes described by $U_{n j t}=\alpha_{n j}+\beta_{j} x_{n j t}+\Sigma_{n j t}$, where $U_{n j t}$ is the utility that individual $n$ receives from choosing $\mathrm{j}$ (to produce feedstocks) in scenario $t, \alpha_{n j}$ is the individual specific intercept for alternative $\mathrm{j}$ arising from n's unobserved preferences, and $\beta_{\mathrm{j}}$ is a vector of coefficients that does not vary over individuals or choice occasions, related to a vector of scenario and individual level attributes xnjt. We estimated the model using Laplace approximation with the lme4 package in R Version 3.0.1 (R Development Core Team, 2013).

\section{Results}

We received responses from 65 of the 126 landowners to whom we mailed the survey, equating to a $49.6 \%$ response rate which is considered acceptable for general population mail-back surveys (Dillman et al. 2008). Five respondents indicated the property queried about had changed ownership, therefore the following analyses are based on a sample of 60 landowners and their forested properties. Landowners that responded to the stated preference survey were typically male (72\%) and an average of 64 years old. All of the participants were high school graduates with $68 \%$ having at least a bachelor's degree. Although our sample of landowners had otherwise similar characteristics to those of the broader population of private forest owners nationwide, they do appear to have a higher level of education (Butler, 2008). The forested properties owned by respondents ranged in size from one to fifty hectares, smaller than the nationwide average but representative of privately owned forested properties in the region. Landowners had owned those properties for between two and fifty-eight years (mean $=20.5, \mathrm{SD}=12.5)$ and only a small percentage of them $(17 \%)$ currently harvest timber from their land for income generation.

Landowners' interest in harvesting bioenergy feedstocks ranged from $13 \%$ to $62 \%$ of the sampled population, depending on the sce- nario attributes (Table 2). The management plan most frequently chosen by landowners was stand thinning, followed by conventional harvest and short-rotation plans. For each management type, woodland owners were consistently interested in plans yielding greater economic return, however the popularity of scenarios did not correspond to the discounted present value of harvest. The majority of landowners interested in producing woody feedstocks under any scenario are not currently harvesting timber for income. A third of respondents indicated they would never harvest timber for bioenergy, with the most popular reasons being the preexistence of an alternative management plan $(n=5)$, potential harm to wildlife $(n=4)$, and potential aesthetic impacts $(n=3)$. Economic $(n=2)$ and anti-bioenergy sentiments $(n=2)$ were secondary.

The mixed logit model revealed both the type of management plan and projected economic return had significant influences on landowners' contingent decision to produce bioenergy feedstocks. In addition to these effects, the landowner's age and the amount of surrounding farmland in the landscape significantly influenced the decision to produce bioenergy feedstocks (Table 3). Model estimates indicated no statistically significant influence of the landowner's presence, sense of place, the size of their forest, or its property value on the decision.

The probabilities of the average landowner producing bioenergy feedstocks for each type of management plan and the distinct levels of economic return are plotted in Fig. 2; it is important to note these probabilities varied greatly with individual landowner characteristics as illustrated in Fig. 3. Younger landowners in areas with more surrounding farmland were significantly more likely to choose to produce bioenergy feedstocks under any scenario.

\section{Discussion}

Emerging bioenergy markets present new opportunities for forest owners to generate income by producing feedstocks for 
Table 3

Estimates from mixed logit model predicting landowners' probability of producing bioenergy feedstocks.

\begin{tabular}{|c|c|c|c|c|}
\hline Random effects & Mean & Mean & Std dev & \\
\hline Intercept & 3.238 & 3.148 & & \\
\hline Fixed effects & Estimate & Std error & $p$-value & \\
\hline Intercept & 2.927 & 3.101 & 0.345 & \\
\hline Conventional harvest & -3.097 & 0.427 & 0.000 & *** \\
\hline Short-rotation & -3.532 & 0.454 & 0.000 & ${ }^{* * *}$ \\
\hline Economic return $\$ 150$ & 1.357 & 0.418 & 0.001 & ${ }^{* * *}$ \\
\hline Economic return $\$ 250$ & 2.229 & 0.426 & 0.000 & *** \\
\hline Age & -0.097 & 0.050 & 0.055 & * \\
\hline Forest size & 0.019 & 0.054 & 0.721 & \\
\hline Presence & -0.020 & 0.039 & 0.611 & \\
\hline Sense of place & -0.761 & 0.517 & 0.141 & \\
\hline Surrounding farmland & 0.006 & 0.002 & 0.005 & ${ }^{* * *}$ \\
\hline Property value & 0.001 & 0.001 & 0.640 & \\
\hline
\end{tabular}

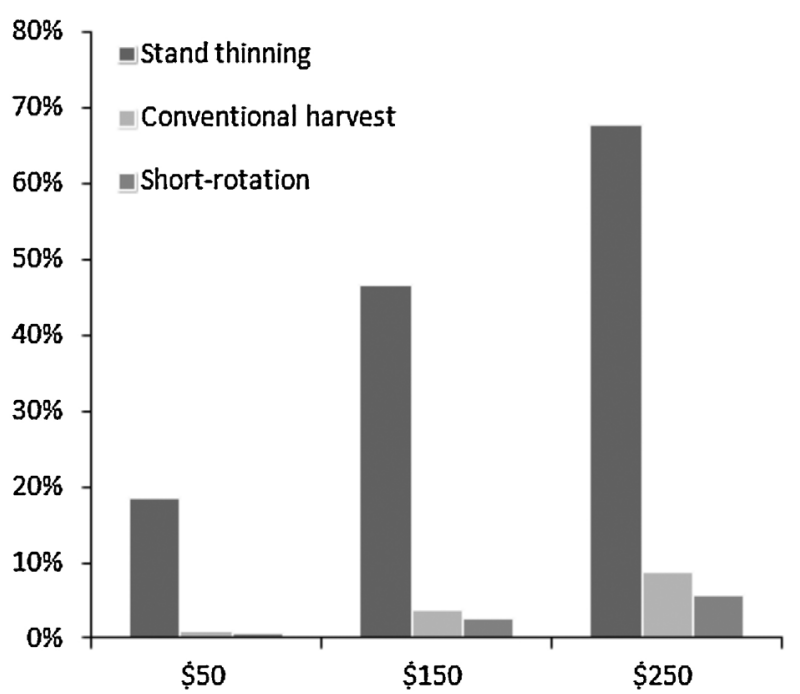

Fig. 2. Probability of feedstock production. The predicted probability (based on logit estimates) of the average landowner choosing to produce bioenergy feedstocks under each scenario. The monetary values along the $x$-axis are per acre per year. bioenergy production (Amacher et al. 2003; Beach et al. 2005), a trend likely to impact the allocation and management of forest resources in the Southeast given the maturation of needed technologies and widespread acceptance of feedstock production practices. In this study we looked specifically at a population of nonindustrial private forest owners in the rapidly urbanizing Charlotte region and found $2 / 3$ of the sample willing to consider feedstock production depending on the type of forest management involved, the expected economic return, their individual socio-demographic characteristics, and local land use patterns. Further, the majority of those willing to produce feedstocks do not currently harvest timber, suggesting bioenergy markets could engage a new population in forest management.

\subsection{Preferences for feedstock production scenarios}

We surveyed forest owners' preferences for a variety of possible forest management plans involving harvesting bioenergy feedstocks by soliciting their response to plausible harvest scenarios that varied in a number of explicit (the type of management plan and the amount of economic return) and implicit (e.g., variable frequencies of economic return, management intensities, and expected ecological and aesthetic impacts) ways. Many respondents preferred stand-thinning, the least intensive harvest strategy allowing the retention of the most trees. These findings are consistent with Joshi et al. (2013b) who found landowners willingness to allow biomass to be harvested from their properties for bioenergy was influenced by the perceived impacts that harvesting would have on local environmental conditions. These results indicate that as the demand for bioenergy increases, we might expect private forest owners to be most attracted to forest management plans that emphasize stand thinning. Landowners had a more limited interest in both conventional harvest and short-rotation management plans. These plans have the least (conventional harvest) and most (short-rotation) frequent economic returns, therefore the immediacy of income seems to be an unlikely factor in their overall popularity. However, these plans require intensive management and the removal of all standing trees, a likely deterrent for many of these woodland owners due to the aesthetic and environmental impacts. Previous research within the region supports this assertion, finding widespread acceptance for forests managed for aesthetic and environmental concerns rather than economic returns (Smith, 2013).
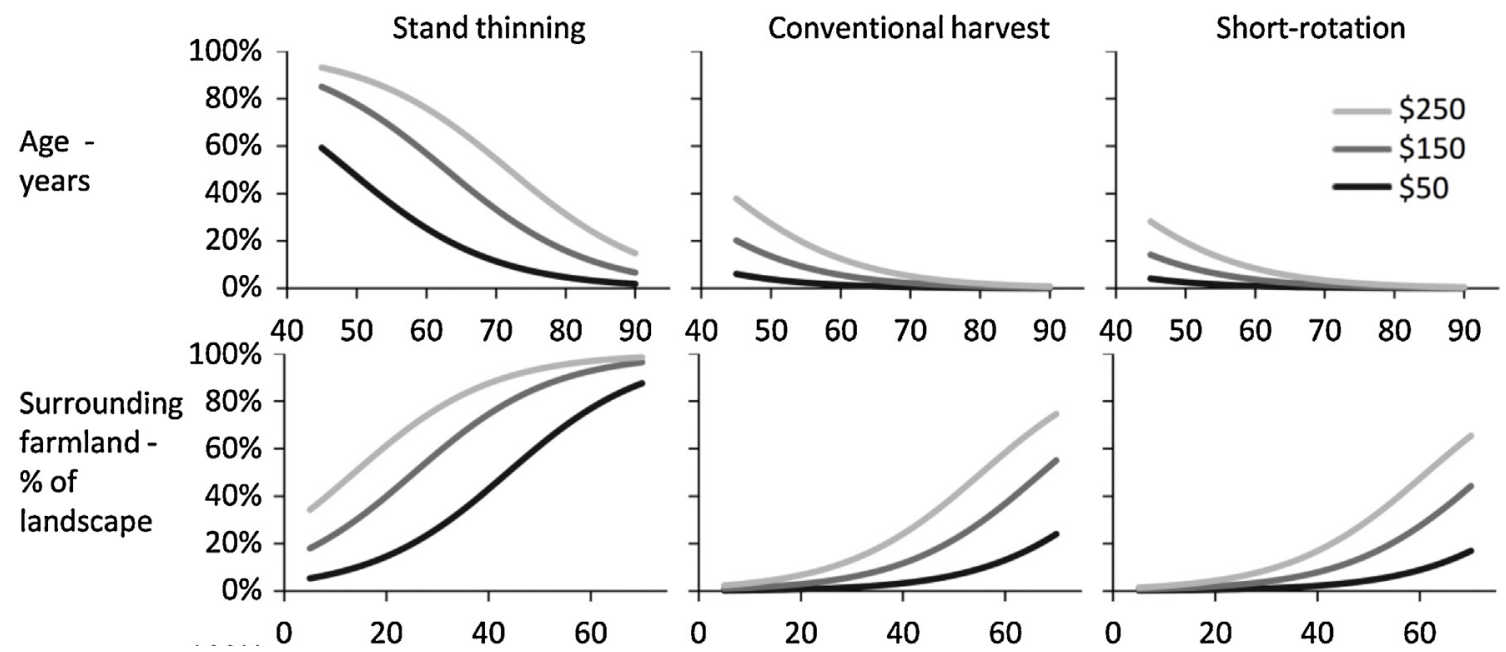

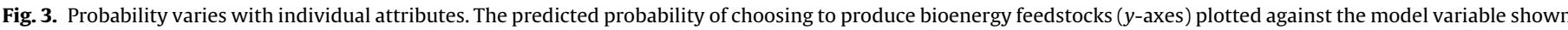
at left ( $x$-axes). Probabilities for each target variable were calculated at the mean of all other model variables. 
Woodland owners strictly uninterested in producing bioenergy feedstocks (33\% of the sampled population) were primarily concerned about impacts to the quality of the forest for their own use and for that of wildlife. This aligns with our assertion that this population of landowners is not motivated primarily by feedstock revenues and highlights a major difference in comparison to farmers in the Midwest, where reservations about switching to feedstock production tended to be driven by monetary concerns (Jensen et al., 2007; Cope et al., 2011). Most of the landowners in this study are not dependent on their land for income (BenDor et al., 2014), thus reducing the risk of change associated with altering land management practices. While landowners preferred higher economic returns within each plan, a post hoc comparison of the popularity of management plans to discounted present value further supports the claim that this group of landowners were not basing their choices strictly on economic returns, but were also considering impacts to other values such as aesthetics or quality of life.

Our analysis, which incorporated data from a previouslyadministered revealed preference survey and spatially-explicit remote sensing data, revealed younger woodland owners in agriculturally dominant landscapes were much more likely to indicate a willingness to provide feedstock for bioenergy production. This finding aligns with previous studies of forest management decisions (Beach et al., 2005, Joshi et al., 2013b). Many older landowners may be resistant to starting a new management practice at a later stage in life. One older landowner even expressed the sentiment that they "did not have that much time left" to invest in a new income generation strategy. Forested parcels embedded within larger amounts of surrounding farmland are presumably located in more rural or predominantly agricultural areas. These forest owners may be generally more inclined to generate income from their properties due to the culture of production existing in these landscapes, and may also own farmland themselves.

While the probability of the average landowner choosing a conventional harvest or a short-rotation plan was small, young landowners in rural areas had a much higher probability of selecting these management intensive plans. For example, the average landowner had only a $5.8 \%$ predicted probability of choosing a short-rotation plan, even with the maximum expected economic return. With all other aspects held constant, a landowner at 45 years of age had a $28 \%$ probability of choosing a short-rotation plan and an average landowner in a predominantly agricultural area (70\% farmland) had a $65 \%$ probability of choosing the plan. This indicates we could see greater changes to the landscape in rural areas where younger landowners are managing forested properties. Given similar studies by Cope et al. (2011) and Beach et al. (2005) we also expected the size and property value of a parcel, an individual's sense of place, and their presence on their property would contribute to their willingness to produce biomass for bioenergy, however none of these factors were statistically significant.

\subsection{Implications for potential bioenergy production practices}

Landowners' receptivity to feedstock production scenarios, coupled with projected increases in demand for bioenergy (Alavalapati et al. 2011), suggests the potential for using woody biomass for bioenergy is a distinct near-term reality for the region. However, landowners' preference for stand thinning presents a challenge to current regional silvicultural practices which can reduce extraction costs via clear cutting; the cost associated with thinning currently makes those stumpage prices non-competitive with conventional harvest techniques (U.S. Department of Energy, 2011). The volume of biomass produced from thinning also pales in comparison to volumes expected from short-rotation plans or full conventional harvests (Skog et al., 2006; Volk et al., 2006; White, 2010). Despite these challenges, thinning practices represent a frontier that should be studied in light of popularity among landowners and potential for increasing best management practices among a group defined by passive or non-management strategies. Given viable markets for stand thinning, we could expect many landowners to engage in management, especially as rates of economic return increase. Further research is needed to understand the full suite of social, economic, and environmental trade-offs between management extensive (across larger land areas and more forest owners - as in stand thinning) and management intensive (across smaller land areas with fewer forest owners) approaches.

\subsection{Potential landscape scale impacts}

The production of bioenergy under any management plan would expand or intensify management and harvesting practices in this region, acting as an additional extractive force on forest resources already under pressure from expanding urbanization (Guo et al., 2010; Evans et al., 2013; Dorning et al., 2015). The engagement of landowners not currently managing their forests for income may amplify harvesting activities; of the landowners interested in growing feedstocks in this study, only $17 \%$ currently harvest timber from their forest. In the most extreme cases, mature forests could be converted to short-rotation cropping systems with completely different ecosystem functions; these activities may decrease nutrient retention in soils, alter wildlife habitat structure, and cause changes in carbon cycling and sequestration (Littlefield and Keeton, 2012; Schulze et al., 2012).

Alternatively, there could be social, economic, and ecological benefits to the expansion and intensification of regional bioenergy production systems. As an example, urbanization pressures have increased the tax and opportunity costs of urban forest owners throughout the region who rarely qualify for offsets provided by present use value programs (BenDor et al., 2014). The novelty of producing "green energy" and income generation from feedstock sales from stand thinning may provide landowners with new reasons to maintain their forested properties rather than seek relief by selling to developers, conserving those remnant forest functions.

While at first glance this seems like a win-win situation for landowners and forests, it remains unclear whether stand thinning would have predominantly positive or negative impacts on environmental and ecological systems. Even with the best intentions, stand thinning may adversely impact wildlife habitat quality (Verschuyl et al., 2011). Since this strategy was most popular among landowners it is essential to conduct further research to understand how thinning would affect forest ecosystems.

\subsection{Limitations}

This study is based on one small sample of urban forest owners in central North Carolina. It is likely the interests of different landowner populations will vary based upon their needs and characteristics. Expansion of this study to a larger sample of forest owners would allow us to make more definitive and generalizable statements about landowners' preferences for forest management strategies involving harvesting biomass for bioenergy production. Future studies with samples drawn from nationwide sampling frames would also facilitate the exploration of differences across distinct landowner types, feedstocks, and dominant land use patterns. While the results of our empirical analysis are not generalizable to all non-industrial private forest owners, our findings can be used to guide local land use planning and woody biomass production planning efforts. Additional studies of landowners in the Southeast should target a wide selection of landowner types (e.g., 
industrial timber producers and farmers) to understand how these populations will respond to emerging markets and subsequent changes to land management. Future in-depth qualitative research (e.g., Silver et al., 2015) should also be pursued in an effort to reveal additional or alternative relationships between private forest management strategies and landowners' values, opinion, beliefs, and attitudes.

As previously noted, the management scenarios in this study can vary implicitly, making it difficult to tease apart the motivations behind landowner choices. It would be advantageous to more explicitly address these motivations to determine whether landowners choose management options based on the frequency of economic return, management level required, or expected ecological and aesthetic impacts. We have not analyzed the feasibility or economic viability of implementing the landowners' preferred management scenarios, particularly in association with the forest's location or size. Some landowners, such as those already connected to forest products supply chains, may be better positioned to take advantage of woody biomass markets (Rentizelas et al., 2009). With additional information regarding these details, we may be able to better estimate the amount of biomass that can be provided from southern forests and the potential impacts to forest resources across the region.

\subsection{Conclusions}

The emergence of a bioenergy market based on woody biomass will likely affect landowners and landscapes in the Southeastern United States. Landowners presented with new opportunities for income generation might change their management practices, subsequently altering the pattern and function of forested landscapes. However the acceptance of requisite harvest practices is far from universal, and potential adopters in this study were selective about harvest regimes, favoring low intensity practices over increased revenue streams associated with short-rotation harvests. Younger woodland owners in agricultural settings countered this proclivity to some degree, yet a desire to leave current priorities undisturbed led a third of the respondents to reject any possibility of feedstock harvests. The evolution of the bioenergy market, competition with other land use types, and the management decisions made by all forest owners will continue to be key drivers in shaping the structure and function of future forested landscapes.

\section{Acknowledgements}

This research was funded by the NSF ULTRA-EX Program (Grant \#0948181). The authors would like to thank Todd BenDor, JeanClaude Thill, and other members of Charlotte ULTRA-Ex research team at the University of North Carolina at Charlotte for their support in the development of this project. We would also like to thank two anonymous reviewers whose comments greatly improved the content of this manuscript.

\section{Appendix A. Stated preference survey question}

\section{A.1. Stated preference survey question}

\section{Harvest for Biofuels}

Recent renewable energy strategies have included a focus on biofuels, which can be derived from woodland plant materials. Forest owners within North Carolina can use their existing forest resources to create these biofuels using one of many possible management plans, with economic returns varying with the market for biomass. Possible management options are outlined on the following page.

\begin{tabular}{|c|c|}
\hline Stand Thinning & $\begin{array}{l}\text { A selection of uneven-aged trees are removed } \\
\text { and sold as timber, while smaller trees, } \\
\text { branches, and other materials are sold to } \\
\text { create biofuels. Stand thinning can be repeated } \\
\text { approximately every } 10 \text { years while still } \\
\text { maintaining woodland cover. }\end{array}$ \\
\hline Conventional Harvest & $\begin{array}{l}\text { Nearly all trees are removed with the more } \\
\text { valuable trees sold as timber and smaller trees, } \\
\text { branches, and other materials sold to create } \\
\text { biofuels. The woodland is allowed to } \\
\text { regenerate over the next } 50 \text { years before } \\
\text { another harvest is possible. }\end{array}$ \\
\hline Short-Rotation & $\begin{array}{l}\text { Following a conventional harvest, a single tree } \\
\text { species (often willow or poplar) is planted at a } \\
\text { high density. All trees are harvested and } \\
\text { replanted approximately every } 5 \text { years with all } \\
\text { parts of the tree sold to create biofuels. }\end{array}$ \\
\hline
\end{tabular}

We are interested in whether or not you would consider selling woody materials for biofuel production depending on the type of management plan used and its expected economic return. Please evaluate the following nine scenarios and indicate the percentage of your wooded land you would dedicate to biofuel production for each. Note that the frequency of economic return varies depending on the management plan as described above. Here, economic returns are described as the amount you would expect to receive per acre per year, with per acre per harvest values shown in parentheses. For example, in the first scenario the rate of economic return is $\$ 50$ per acre per year. Since stand thinning can be conducted every 10 years, you would receive $\$ 500$ per acre every ten years.

\begin{tabular}{|c|c|c|c|}
\hline Scenario & Management plan & $\begin{array}{l}\text { Economic return - } \\
\text { per acre per year (per } \\
\text { acre per harvest) }\end{array}$ & $\begin{array}{l}\text { Amount of woodland } \\
\text { dedicated to biofuel } \\
\text { production }\end{array}$ \\
\hline 1 & Stand thinning & $\$ 50(\$ 500)$ & \% \\
\hline 2 & $\begin{array}{l}\text { Conventional } \\
\text { harvest }\end{array}$ & $\$ 150(\$ 7500)$ & $\%$ \\
\hline 3 & Short-rotation & $\$ 250(\$ 1250)$ & \% \\
\hline 4 & Short-rotation & $\$ 150(\$ 750)$ & $\%$ \\
\hline 5 & $\begin{array}{l}\text { Conventional } \\
\text { harvest }\end{array}$ & $\$ 50(\$ 2500)$ & $\ldots$ \\
\hline 6 & Stand thinning & $\$ 250(\$ 2500)$ & \% \\
\hline 7 & $\begin{array}{l}\text { Conventional } \\
\text { harvest }\end{array}$ & $\$ 250(\$ 12,500)$ & __ \\
\hline 8 & Short-rotation & $\$ 50(\$ 250)$ & \% \\
\hline 9 & Stand thinning & $\$ 150(\$ 1500)$ & \\
\hline
\end{tabular}

I would never harvest timber from my wooded land for biofuels. Why not?

\section{Appendix B. Survey questions - sense of place}

\section{B.1. Survey questions - sense of place}

\begin{tabular}{|c|c|c|}
\hline Statement & Mean & Std dev \\
\hline Everything about my wooded land is a reflection of me* & 2.83 & 1.63 \\
\hline $\begin{array}{l}\text { I feel that I can really be myself when I am on my wooded } \\
\text { land }\end{array}$ & 3.58 & 1.54 \\
\hline My wooded land reflects the type of person I am & 3.02 & 1.58 \\
\hline I feel relaxed when I'm on my wooded land & 3.92 & 1.39 \\
\hline I feel happiest when I'm on my wooded land & 3.5 & 1.51 \\
\hline My wooded land is my favorite place to be & 3.32 & 1.52 \\
\hline $\begin{array}{l}\text { I really miss my wooded land when I'm away from it for } \\
\text { too long }\end{array}$ & 2.68 & 1.71 \\
\hline $\begin{array}{l}\text { My wooded land is the best place for doing the things that } \\
\text { I enjoy most }\end{array}$ & 2.92 & 1.53 \\
\hline For doing the things that I enjoy most, no other place can & 2.53 & 1.45 \\
\hline
\end{tabular}

compare to my wooded land

${ }^{*}$ Responses were given on a 5-point Likert scale with $1=$ complete disagreement and $5=$ complete agreement. 


\section{References}

Abt, R.C., Abt, K.L., Cubbage, F.W., Henderson, J.D., 2010. Effect of policy-based bioenergy demand on southern timber markets: a case study of North Carolina. Biomass Bioenergy 34, 1679-1686.

Adegbidi, H.G., Volk, T.A., White, E.H., Abrahamson, L.P., Briggs, R.D., Bickelhaupt, D.H., 2001. Biomass and nutrient removal by willow clones in experimental bioenergy plantations in New York State. Biomass Bioenergy 20, 399-411.

Alavalapati, J.R.R., Lal, P., Susaeta, A., Abt, R.C., Wear, D.N., 2011. Chapter 10: Fores Biomass-based Energy. The Southern Forest Futures Project: Technical report (pp. 1-153). USDA Forest Service, Southern Research Station.

Amacher, G.S., Conway, C.M., Sullivan, J., 2003. Econometric analysis of nonindustrial forest landowners: is there anything left to study? J. Forest Econ. 9, 137-164.

American Forests, 2010. Urban ecosystem analysis, Mecklenburg County and the City of Charlotte, North Carolina: calculating the value of nature. American Forests, Washington, D.C., USA. [online] URL: Services/LandDevelopment/trees/TreeCommission/Documents/Charlotte_final.pdf 2010; http://www.charmeck.org/city/charlotte/epm/

Barlow, S.A., Munn, I.A., Cleaves, D.A., Evans, D.L., 1998. The effect of urban sprawl on timber harvesting: a look at two southern states. J. Forest. 96 (10), 14

Beach, R.H., Pattanayak, S.K., Yang, J.C., Murray, B.C., Abt, R.C., 2005. Econometric studies of non-industrial private forest management: a review and synthesis. Forest Policy Econ. 7 (3), 261-281.

BenDor, T.K., Shoemaker, D.A., Thill, J.C., Dorning, M.A., Meentemeyer, R.K., 2014. A mixed-methods analysis of socio-ecological feedbacks between urbanization and forest persistence. Ecol. Soc. 19 (3), 3.

Bennett, J., Blamey, R. (Eds.), 2001. Edward Elgar Publishing, Cheltenham, UK.

Butler, B.J., 2006. Family Forest Owners of the United States, 2006. Gen. Tech. Rep. NRS-27. Newtown Square. Department of Agriculture, Forest Service, PA, U.S Northern Research Station, pp. 2008.

Cope, M.A., McLafferty, S., Rhoads, B.L., 2011. Farmer attitudes toward production of perennial energy grasses in East Central Illinois: implications for community-based decision making. Ann. Assoc. Am. Geogr. 101, 852-862.

Dale, V.H., Kline, K.L., Wright, L.L., Perlack, R.D., Downing, M., Graham, R.L., 2011 Interactions among bioenergy feedstock choices, landscape dynamics, and land use. Ecol. Appl. 21, 1039-1054

Dillman, D.A., Smyth, J.D., Christian, L.M., 2008. Internet, Mail, and Mixed-mode Surveys: The Tailored Design Method. Wiley, New York, NY, USA.

Dorning, M.A., Koch, J., Shoemaker, D.A., Meentemeyer, R.K., 2015. Simulating urbanization scenarios reveals tradeoffs between conservation planning strategies. Landscape Urban Plann. 136, 28-39.

Energy Independence and Security Act of 2007 2007. Public Law 110-140, H.R. 6.

Evans, J.M., Fletcher Jr., R.J., Alavalapati, J.R.R., Smith, A.L., Geller, D., Lal, P., Vasudev, D., Acevedo, M., Calabria, J., Upadhyay, T., 2013. Forestry Bioenergy in the Southeast United States: Implications for Wildlife Habitat and Biodiversity. National Wildlife Federation and Southern Environmental Law Center, Washington, D.C.

Fargione, J., Hill, J., Tilman, D., Polasky, S., Hawthorne, P., 2008. Land clearing and the biofuel carbon debt. Science 319, 1235-1238.

Field, C.B., Campbell Lobell, J.E.D.B., 2008. Biomass energy: the scale of the potential resource. Trends Ecol. Evol. 23, 65-72.

Fletcher, R.J., Robertson, B.A., Evans, J., Doran, P.J., Alavalapati, J.R.R., Schemske, D.W., 2011. Biodiversity conservation in the era of biofuels: risks and opportunities. Front. Ecol. Environ. 9, 161-168.

Forest2Market, North Carolina Timber Report. 3rd Quarter Accessed from 2012; http://www.ces.ncsu.edu/forestry/resources/price_report.php

Gelman, A., Hill, J., 2007. Data Analysis Using Regression and Multilevel/hierarchical Models. Cambridge University Press, New York, NY, USA.

Grebner, D.L., Perez-Verdin, G., Henderson, J.E., Londo, A.J., 2009. Bioenergy from woody biomass, potential for economic development, and the need for extension. J. Extension 47, 6FEA7.

Gruchy, S.R., Grebner, D.L., Munn, I.A., Joshi, O., Hussain, A., 2012. An assessment of nonindustrial private forest landowner willingness to harvest woody biomass in support of bioenergy production in Mississippi: a contingent rating approach. Forest Policy Econ. 12 (2), 140-145

Guo, Z., Grebner, D.L., Sun, C., Grado, S.C., 2010. Evaluation of loblolly pine management regimes in Mississippi for biomass supplies: a simulation approach. Southern J. Appl. Forest. 34 (2), 65-71.

Hinchee, M., Rottmann, W., Mullinax, L., Zhang, C., Chang, S., Cunningham, M., Pearson, L., Nehra, N., 2009. Short-rotation woody crops for bioenergy and biofuels applications. In Vitro Cell. Dev. Biol.-Plant 45, 619-629.

Corp, I.B.M., 2012. IBM SPSS Statistics for Windows, Version 21.0. IBM Corp., Armonk, NY.

Jensen, K., Clark, C.D., Ellis, P., English, B., Menard, J., Walsh, M., de la Torre Ugarte, D., 2007. Farmer willingness to grow switchgrass for energy production. Biomass Bioenergy 31, 773-781.

Johnson, D., Knoepp, J.D., Swank, W.T., Shan, J., Morris, L., Van Lear, D., Kapeluck, P., 2002. Effects of forest management on soil carbon: results of some long-term resampling studies. Environ. Pollut. 116, S201-S208.

Johnson, D.W., Curtis, P.S., 2001. Effects of forest management on soil C and N storage: meta analysis. Forest Ecol. Manage. 140, 227-238.

Jorgensen, B.S., Stedman, R.C., 2006. A comparative analysis of predictors of sense of place dimensions: attachment to, dependence on, and identification with lakeshore properties. J. Environ. Manage. 79, 316-327.
Joshi, O., Grebner, D.L., Hussain, A., Grado, S.C., 2013a. Landowner knowledge and willingness to supply woody biomass for wood-based bioenergy: sample selection approach. J. Forest Econ. 19, 97-109.

Joshi, O., Grebner, D.L., Munn, I.A., Hussain, A., Gruchy, S.R., 2013b. Understanding landowner preferences for woody biomass harvesting: a choice experiment-based approach. Forest Sci. 59, 549-558.

Joshi, O., Mehmood, S., 2011. Factors affecting nonindustrial private forest landowners' willingness to supply woody biomass for bioenergy. Biomass Bioenergy 35 (1), 186-192.

Kline, J.D., Azuman, D.L., Alig, R.J., 2004. Population growht, urban expansion, and private forestry in Western Oregon. Forest Sci. 50 (1), 33-43.

Littlefield, C.E., Keeton, W.S., 2012. Bioenergy harvesting impacts on ecologically important stand structure and habitat characteristics. Ecol. Appl. 22, 1892-1909.

Louviere, J.J., Hensher, D.A., Swait, J.D., 2000. Stated Choice Methods: Analysis and Application. Cambridge University Press, New York, NY, USA, pp. 2000.

MacFarlane, D.W., 2009. Potential availability of urban wood biomass in Michigan: implications for energy production, carbon sequestration and sustainable forest management in the USA. Biomass Bioenergy 33, 628-634.

McFadden, D., 1974. Conditional logit analysis of qualitative choice behaviour. In: Zarembka, P. (Ed.), Frontiers of econometrics (pp. 105-142). Academic Press, New York, NY, USA.

McKeever, D.B., Skog, K.E., 2003. Urban Tree and Wood Yard Residues Another Wood Resource. Research Note: FPL-RN-0290 USDA Forest Service. Forest Products Laboratory, Madison, WI, USA.

Meentemeyer, R.K., Tang, W., Dorning, M.A., Vogler, J.B., Cunniffe, N.J., Shoemaker, D.A., 2013. FUTURES: multilevel simulations of emerging urban-rural landscape structure using a stochastic patch-growing algorithm. Ann. Assoc. Am. Geogr. 103, 785-807.

Nassauer, J.I., Dowdell, J.A., Wang, Z., McKahn, D., Chilcott, B., Kling, C.L., Secchi, S., 2011. Iowa farmers' responses to transformative scenarios for Corn Belt agriculture. J. Soil Water Conserv. 66, 18A-24A.

Nunnally, J.C., Bernstein, I.H., 1994. Psychometric Theory, 3rd ed. McGraw Hill, New York, NY, USA.

Perez-Verdin, G., Grebner, D.L., Sun, C., Munn, I.A., Schultz, E.B., Matney, T.G., 2009. Woody biomass availability for bioethanol conversion in Mississippi. Biomass Bioenergy 33, 492-503.

Plantinga, A.J., Lubowski, R.N., Stavins, R.N., 2002. The effects of potential land development on agricultural land prices. J. Urban Econ. 52, 561-581.

R Development Core Team, 2013. R: A language and environment for statistical computing. R Foundation for Statistical Computing, Vienna, Austria URL 2013; http://www.R-project.org

Rentizelas, A.A., Tolis, A.J., Tatsiopoulos, I.P., 2009. Logistics issues of biomass: the storage problem and the multi-biomass supply chain. Renew. Sustain. Energy Rev. 13 (4), 887-894.

Robertson, G.P., Dale, V.H., Doering O.C., Hamburg S.P., Melillo, J.M., Wander, M.M., Parton, W.J., Adler, P.R., Barney, J.N., Cruse, R.M., 2008. Sustainable biofuels redux. Science 322, 49-50.

Ryan, M., Skåtun, D., 2004. Modelling nonådemanders in choice experiments. Health Econ. 13 (4), 397-402.

Schulze, E.D., Körner, C., Law, B.E., Haberl, H., Luyssaert, S., 2012. Largeöscale bioenergy from additional harvest of forest biomass is neither sustainable nor greenhouse gas neutral. GCB Bioenergy 4, 611-616.

Scott, D.A., Tiarks, A., 2008. Dual-cropping loblolly pine for biomass energy and conventional wood products. Southern J. Appl. Forest. 32, 33-37.

Shivan, G.C., Mehmood, S.R., 2010. Factors influencing nonindustrial private forest landowners' policy preference for promoting bioenergy. Forest Policy Econ. 12, 581-588.

Shivan, G.C., Mehmood, S.R., 2012. Determinants of nonindustrial private forest landowner willingess to accept price offers for woody biomass. Forest Policy Econ. 25, 47-55

Sikkema, R., Steiner, M., Junginger, M., Hiegl, W., Hansen, M.T., Faaij, A., 2011. 2011. The European wood pellet markets: current status and prospects for 2020. Biofuels Bioprod. Biorefin. 5, 250-278.

Silver, E.J., Leahy, J.E., Noblet, C.L., Weiskittel, A.R., 2015. Maine woodland owner perceptions of long rotation woody biomass harvesting and bioenergy. Biomass Bioenergy 76, 69-78.

Singh, K.K., Vogler, J.B., Shoemaker, D.A., Meentemeyer, R.K., 2012. LiDAR-Landsat data fusion for large-area assessment of urban land cover: balancing spatial resolution, data volume and mapping accuracy. ISPRS J. Photogramm. Remote Sens. 74, 110-121.

Skog, K.E., Barbour, R.J., Abt, K.L., Bilek, E.M., Burch, F., Fight, R.D., Hugget, R.J., Miles, P.D., Reinhardt, E.D., Shepperd, W.D., 2006. Evaluation of Silvicultural Treatments and Biomass Use for Reducing Fire Hazard in Western States. Research Paper FPL-RP-634. Department of Agriculture, Forest Service, Forest Products Laboratory, Madison, WI, U.S, 29 p.

Smith, J.W., 2013. Adaptive participation in forest planning contingent upon a hypothetical large-scale forest disturbance. Forest Sci. 59 (6), 637-648.

Stanton, B., Eaton, J., Johnson, J., Rice, D., Schuette, B., Moser, B., 2002. Hybrid poplar in the Pacific Northwest: the effects of market-driven management. J. Forest. 100, 28-33.

Thomas, S.C., Halpern, C.B., Falk, D.A., Liguori, D.A., Austin, K.A., 1999. Plant diversity in managed forests: Understory responses to thinning and fertilization. Ecol. Appl. 9, 864-879.

Train, K.E., 2009. Discrete Choice Methods with Simulation. Cambridge University Press, New York, New York, USA. 
US Department of Energy, 2011. U.S. Billion-Ton Update: Biomass Supply for a Bioenergy and Bioproducts Industry. R.D. Perlack and B.J. Stokes (Leads), ORNL/TM-2011/224. Oak Ridge National Laboratory, Oak Ridge, TN, 227p.

Verschuyl, J., Riffell, S., Miller, D., Wigley, T.B., 2011. Biodiversity response to intensive biomass production from forest thinning in North American forests a meta-analysis. Forest Ecol. Manage. 261, 221-232.

Volk, T., Abrahamson, L., Nowak, C., Smart, L., Tharakan, P., White, E., 2006. The development of short-rotation willow in the northeastern United States for bioenergy and bioproducts, agroforestry and phytoremediation. Biomass Bioenergy 30, 715-727.
White, E.M., 2010. Woody Biomass for Bioenergy and Biofuels in the United States-a Briefing Paper. Gen. Tech. Rep. PNW-GTR-825. Department of Agriculture, Forest Service, Portland, OR: U.S., Pacific Northwest Research Station.

White, E.M., Latta, G., Alig, R.J., Skog, K.E., Adams, D.M., 2014. Biomass production from the U.S. forest and agriculture sectors in support of a renewable electricity standard. Energy Policy 58, 64-74. 